\title{
Myelin Transcription Factor 1-Like Protein
}

National Cancer Institute

\section{Source}

National Cancer Institute. Myelin Transcription Factor 1-Like Protein. NCI Thesaurus. Code C82899.

Myelin transcription factor 1-like protein (1186 aa, $133 \mathrm{kDa}$ ) is encoded by the human MYT 1L gene. This protein is involved in the regulation of transcription during neuronal development. 